1040

日本機械学会論文集 $(\mathrm{A}$ 編 $)$

76 巻 768 号 $(2010-8)$

論文 No. 09-1000

一般化線形混合モデルを用いた逆問題による損傷同定の高精度化*

（電気ポテンシャル法を用いた CFRP 積層構造のはく離同定への適用）

岩崎篤*1, 轟章*2

\title{
Improvement of the Inverse Problem for the Damage Identification Using Generalized Linear Mixed Model \\ (Application to the Delamination Identification via Electric Potential Method of CFRP Laminate)
}

Atsushi IWASAKI*3 and Akira TODOROKI

*33 Department of Mechanical System Engineering, Gunma University, 1-5-1 Tenjin-cho, Kiryu-shi, Gunma, 376-8515 Japan

\begin{abstract}
This paper is about improvement of diagnostic accuracy of the damage identification applying the generalized linear mixed model to the inverse problem. Generalized linear mixed model (GLMM) is the extend method of the linear regression analysis include the random effect. By the method, relation between the dependent variable and the independent variables are divided to fixed effect and random effect. The fixed effect means true relation and the random effect means the unknown fluctuation because of the individual specificity. When the damage diagnosis conducted by the inverse problem, this unknown fluctuation is caused by not only the difference of the lot of test piece, but also the unknown parameters of the damage. For example, for the damage size identification problem, location of the damage is the unknown parameter. This unknown parameter is unknown at the time of damage identification but this unknown parameter is known at the time of constructing the model of the inverse problem and the time of deciding the parameter for the inverse problem model. Then in this research, improvement of diagnostic accuracy of the damage identification using inverse problem via the GLMM is conducted. The method is applied to the delamination identification via electric potential method of CFRP laminate. FEM analyses are conducted to obtain electric potential changes due to delamination crack creations with seven-electrode type specimens. By comparisons of the estimations without the random effect and with the effect, a better diagnostic tool is discussed in detail. As a result, GLMM improve the diagnostic accuracy of size and location identification of the delamination crack.
\end{abstract}

Key Words: Smart Structure, Generalized Linear Mixed Model, GLMM, Inverse Problem, Structural Reliability, Nondestructive Inspection, Statistical Treatment, Damage Identification, Damage Evaluation, Composite Material, Delamination

\section{1. 緒言}

本稿は, 線型混合モデルを用いた逆問題による損傷 同定問題の高精度化に関する物である.

損傷や異常の同定における逆問題解析叫推定誤差最 小化の最適化問題であり，応答曲面 ${ }^{30}$, ニューラルネ ットワーク 579, 局所フレキシビリティ法 ${ }^{1011}$ や遺伝的ア ルゴリズムなどの様々な最適化手法を用いた手法や， マハラノビス距離等による判別分析 ${ }^{(2-14)}$ ，サポートベク ターマシン151わや空間統計学18)などさまざまな統計処理 法を用いた手法が検討されている。一般に，損傷すな

* 原稿受付 2009 年 10 月 30 日.

*1 正員, 群馬大学太学院工学研究科 (事 376-8515 桐生市天神 町 $1-5-1$ ).

*2 正員, 東宗工業大学大学院理工学研究科(曾) 152-8552 東京 都目黒区大网山 2-12-1).

E-mail : aiwasaki@gunma-u.ac.jp
わち被説明変数と計測量の相関を複雑な内部モデルで 同定することで高精度化されるが，これはモデル構築 に用いられたデータに限定され，複雑すぎるモデルは， 学習に用いたデー夕以外の推定精度，すなわち汎化能 力が極端に低下させる. 汎化能力とモデルの複雑化に よる高精度化はほぼトレードオつの関係にある，その ため，最適な逆解析モデルの生成に試行錯誤が必要で あり，一つのモ゙゙ルの導出に繰り返し学習が必要な為 多くの計算コスト・人的コストを要求する。

そこで本研究では，汎化能力向上のため1次の線形回 帰を用いた損傷同定を行い，単純な逆解析モデルの高 精度化の検討を行う。線形・非線形回帰法として近年 注目されている手法として一般化線形混合モデル1921)が ある. 回帰分析では，説明変数と被説明変数の相関強 度評価を行い，無相関あるいは相関の無いパラメータ 
の削減を行いその回帰・汎化性能の向上を行うが，説 明変数に導入されないパラメータはすべて䛊差とし， 正規分布で近似する，一般化線形混合モデルでは，誤 差構造に正規性を必要とせず，また，説明変数と被説 明変数の相関を固定効果とランダム効果に分割する。 固定効果は真の相関を表し，ランダム効果は個体差等 に起因する未知の変動を表す，損傷同定問題において は，例えば試験片の個体差，素材のロットなどが末知 の個体差として考えられるが，なによりも逆解析モデ ル構築時は既知でありながら，診断時には未知のパラ メー夕（寸法同定における損傷位置など）が未知の個 体差として考えられる. そこで本研究では，この未知 の差を一般化線形混合モデルで分割し，低次の回州モ デルを用いた損傷同定の高精度化の検討を行った．本 稿では，複合材料積層平板の電気ポテンシャル法を用 Wた損傷評価問題入之適用し，解析的手法加本手法 の有效性の検証を行った.

\section{2 電気ポテンシャル法を用いた層間はく離評価}

$2 \cdot 1$ 概要 本稿では, 電気ポテンシャル法4(222) を用いたCFRP短冊試験片の層間はく離同定を行った. 以下に概要を示す. CFRPは比剛性, 比強度の力学特性 が優れているため, 航空機や宇宙機器などの主構造へ の適用が検討されている。しかし，層間強度が弱いた め, 弱い衝撃で外側から目視できない層閒はく離を容 易に発生し，压縮特性が著しく低下する．特に，近年 では新型の大型航空機の主構造への適用が進んでおり, その簡便な評価法が望まれている. そこで本研究は CFRPに強化瀻維として埋ぬ込まれている炭素䋊維の導 電性に着目し，CFRPを構成する炭素䋐維がそのまま神 経のような役割を有し，損傷を検出する電気ポテンシ ヤル法によるスマート複合材料開発のための知見を得 ることを目的としている.これまでに我々のグループ では，貫通き裂を有するCFRP梁試験片を用いて，はく 離位置と寸法の同定実験を実施し，電気ポテンシャル
法が有効であること，埋没した害層間はく離に対して も本手法が有効であることを実験的手法物よよひ有限

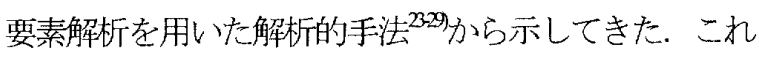
らの手法を実施する上では，測定された電圧変化とは く離の位置, 寸法を結びつける逆問題手法が必要不可 欠である。

$2 \cdot 2$ 解析モデル 解析には沉用有限要素法ソフ

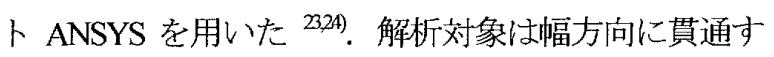
る層間はく離を有する短冊状試験片とし, 図 1 亿示さ れる[02 $\left.190_{2}\right]$ の直交積層板の 2 次元梁モデルとしてモデ ル化を行った. 電極娮験片上面に仮定した. モデル 汁試験片長手方向を $0^{\circ}$ 方向とし, 電極は $0^{\circ}$ 方向に 7 とし, 各電極間の 6 筒所で電圧変化を取得した. 1 層 の厚さは $0.25 \mathrm{~mm}$ である. 要素は 4 角形 4 接点要素と し, $0^{\circ}$ 方向, $90^{\circ}$ 方向を各々 $025,0.05 \mathrm{~mm}$ として要素分 割を行った．要素数は 28160 である. 瀻維方向 $\left(0^{\circ}\right.$ 方 向）,繊維直交方向 $\left(90^{\circ}\right.$ 方向）各層および厚さ方向の 導電率 $\sigma_{b b} \sigma_{9 b} \sigma_{l}$ は体積䋊維含有率 0.621 の場合の実験結 果を用いている（表 1 ）。計測は2電極法で行われる とし, 電告変化量は隣接寸る二つの電極の一方を $0[\mathrm{~V}]$ に固定し, 他方の電極から $30[\mathrm{~mA}]$ の電流を流して, 導出している. また，層間はく䧹は各層間の導電性を 断つことでモデル化している．層間はく離は寸法 5, 10, $20,30,40[\mathrm{~mm}] の 5$ 種とし，はく離中央位置を試験端部 から逆端まで $5 \mathrm{~mm}$ ずつ変え解析を行った。

Table 1 Electric conductivity ratio $\sigma$ of each direction of CFRP

\begin{tabular}{|c|c|c|c|}
\hline Volume fraction of CF & $\sigma_{90} / \sigma_{0}$ & $\sigma_{i} / \sigma_{0}$ & $\sigma_{0}\left[\Omega^{-1} \mathrm{~m}^{-1}\right]$ \\
\hline 0.621 & $3.71 * 10-2$ & $3.77^{*} 10-3$ & $5.50^{*} 103$ \\
\hline
\end{tabular}

\section{3. 一般化線形混合モデルを用いた電気ポテンシャ ル法によるはく離同定}

$3 \cdot 1$ 概要 電気ポテンシャル法によるはく離損 傷同定問題では，はく離発生に起因する電圧変化が電 極功の距離に念じ变動し，特に電極中央部に有る場

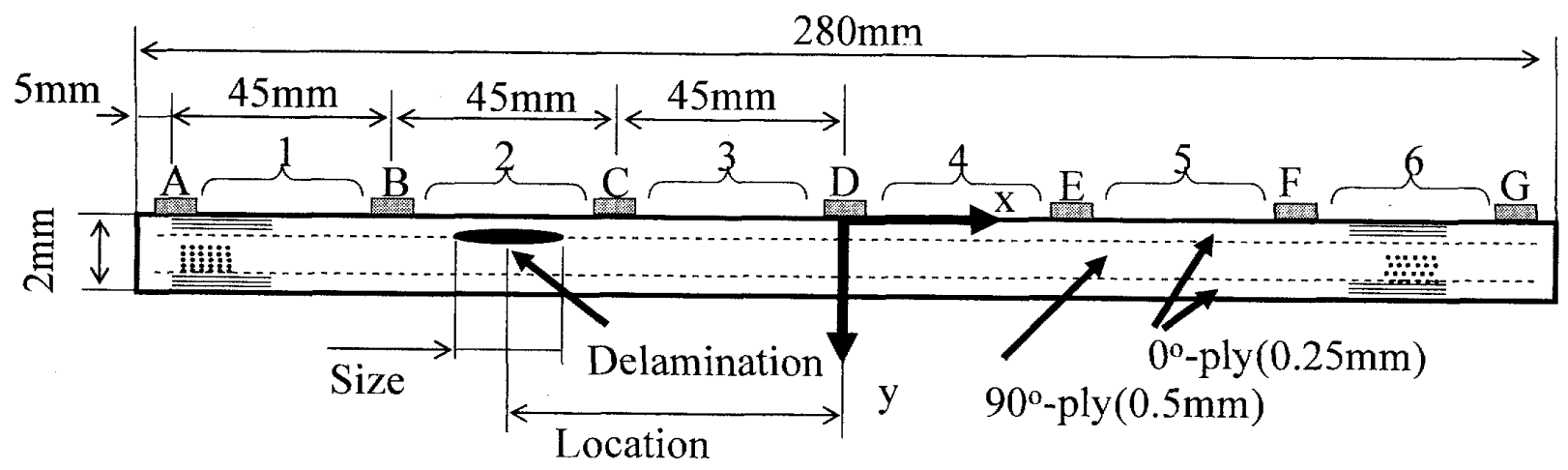

Fig. 1 Model of Specimen 
合その変化量が電極近傍に生じた場合に比べ低く，こ れが計測だけでなく，診断精度へ大きな影響を与える ことが問題である。しかしながら，実際の診断時にお いてはそのはく離発生位置そのものが同定対象であり。 事前に計測することは不可能である，そこで本研究で は，この電極からの距離をランダム要因とし評価する ことにより，一般化線形混合モデルによる同手法の高 精度化を行った。以下に詳細を示す。

$3 \cdot 2$ 一般化線形混合モデル(GLMM) $)^{21)}$ 最小二 乗法に代表される回帰・重回帰分析では，乙の誤差構 造に正規性を有寸る必要が有る。計測䛊差等は一般的 に正規分布に従い回帰分析が適用可能であるとされて いるが，個体差が大きい場合は逸脱が大きく，特にデ ータが離散化されたデータ（損智レベルなど）の場合， 明確に従わない。一般化線型モデルは最尤法により回 帰係数を求めることで，他の分布形状の誤差構造に対 応した回帰モデルである。.また，混合モデル挝被説明 変数と説明変数の相関を，同定が必要な相関（固定効 果），同定が不要な相関（ランダム効果）に分け，固 定効果同定の精度向上を図るモデルである。一般化線 形混合モデルの単回帰のモデルは次式で表される。

$$
y=a+\delta_{1, i}+\left(b+\delta_{2, i}\right) x
$$

ここで, $x, y$ は説明変数, 被説明変数, $a, b$ は固定効果 の切片および傾き， $\delta_{1} ＼delta_{2}$ はそれぞれの個体の変量効 果を示す。すべての変量効果を推定すると自由度は (個体数+1)×2 となり，膨大となるが，一般化線型混 合モデルでは，それぞれの変量効果は推定せず変量効 果の標準偏差 $s_{1}, s_{2}$ の夕を推定卞る。 その際，平均は0 とする. 次式に変量効果の分布形状に正規分布老仮定 した場合の变量効果 $\delta_{1} の$ 確率密度関数老示す。

$$
g\left(\delta_{1, i} \mid s_{1}\right)=\frac{1}{\sqrt{2 \pi} s_{1}} \exp \left\{-\frac{\delta_{1, i}{ }^{2}}{2 s_{1}^{2}}\right\}
$$

反㳊関しても同様である，また，誤差構造が正規分布 からランダム効果が任意の $\delta_{j,} \delta_{2 k}$ の場合に被説明変数 が者をとる確率江次式で表される.

$f\left(y_{i} \mid a, b, \sigma^{2}, \delta_{1, j}, \delta_{2, k}\right)$

$=\frac{1}{\sqrt{2 \pi} \sigma} \exp \left\{-\frac{\left\{y_{i}-\alpha-\delta_{i, j}-\left(b+\delta_{2, k}\right) x_{i}\right\}^{2}}{2 \sigma^{2}}\right\}$

ここで, $\sigma$ は y 標淮偏差である. 被説明変数が $y$ で あるときの尤度 $L_{i}$ は，次式のようにそれぞれのランダ ム効果の積分から次式と定義される。

$$
\begin{aligned}
& L_{i}\left(a, b, \sigma^{2}, s_{1}, s_{2} \mid y_{1}, x_{i}\right) \\
& =\int_{-\infty}^{\infty} \int_{-\infty}^{\infty} f\left(y_{i} \mid a, b, \sigma^{2}, \delta_{1, j}, \delta_{2, k}\right) g\left(\delta_{1, j} \mid s_{1}\right) g\left(\delta_{2, k} \mid s_{2}\right) d \delta_{1} d \delta_{2}
\end{aligned}
$$

そのため全観測データ しに対する尤度は次式となる。

$$
\begin{aligned}
& L\left(a, b, \sigma^{2}, s_{1}, s_{2} \mid\left\{y_{i}\right\},\left\{x_{i}\right\}\right) \\
& =\prod_{i=1}^{n} L_{i}\left(a, b, \sigma^{2}, s_{1}, s_{2} \mid y_{i}, x_{i}\right)
\end{aligned}
$$

ここで, $n$ は観測デー夕数である. 重回帰を行う場合， 説明変数やランダム効果の増大に従い，式は複雑化す る. 最尤推定を行い，対数尤度最大化する $a, b, \sigma, s_{1}$, $s_{2}$ を求めることで，回帰モデルの導出を行う。このよ うな手法を用いることで，個別の個体差を導出する事 無く, 個体差の標準偏差のみを導出寸る事で, 固定効 果の算出を可能とする.

\section{$3 \cdot 3$ 一般化線形湿合モデルによるはく離同定} 本手法では汎化能力を重視し，1次の線形回州を用い た損傷同定を行う。1 次線形回帰に打引る $t$ 検定加 固定効果モデルの選定を行い，同モデルの一般化線形 混合モデルへの適用からランダム効果導入による高精 度化の検証を行う。被説明変数はは離発生位置 $x$ お よびはく離寸法 sze とし, 説明変数は各電極間電圧変 化のベクトル長さ vectorおよび, vectorで規格化した各 電極間電圧変化 $X(\dot{i}-1-6)$ とした，vector および $X_{i}$ の定義 は次式となる.

$$
\begin{aligned}
& \text { vector }=\sqrt{\sum_{i=1}^{6} V_{i}^{2}} \\
& X_{i}=\frac{V_{i}}{\text { vector }}
\end{aligned}
$$

ここでV、は各区間における電圧変化量である.

また，位置，寸法の初期の回帰モデルは次式とし， $t$ 検定を用い变数選択を行う。

$x$ or size $=\beta_{0}+\sum_{i=1}^{6} \beta_{i} X_{i}+\beta_{7}$ vector

ここでßは回信係数である.

$3 \cdot 4 t$ 検定を用いた変数選択 用いる固定効果 の決定には，t検定を用い回帰に不要な誤差項を削隇 し，最良回帰式を選定する，削減甠減少法により行う。 減少法とは, 式(8)中の全項の係数を決定後, 全項を回 州方程式に最後に導入された変数であるかのように扱 W, 各項の $t$ 検定值を算出し, 最も回帰に寄与しない 項，すなわち $t$ 值が最小の項を削減し，回帰精度が最 
大化するまで繰り返し削減することで回慟式を改良す る方法である. 各項の $t$ 検定值 $t_{i}$ は次式で求められる.

$$
t_{i}=\frac{b_{i}}{\sqrt{\sigma^{2} C_{i i}}}
$$

ここで， $b_{i}$ は $\beta_{i}$ の不偏推定量， $\boldsymbol{C}_{\ddot{u}}$ は分散共分散行列で ある。

\section{$3 \cdot 5$ 電極に対するはく離位置の影響＼cjkstart電気ポテ} ンシャル法では，電圧変化の絶対值が，損傷寸法だけ ではなく損傷の電極からの距離に大きく依存し，位置, 寸法の同定精度に悪影響を及ぼす．図 2 に $20 \mathrm{~mm} の$ はく離が生じた場合の, 最も近い電極からの距離に対 する vectorを示寸．回帰モデルの導出時には，この電 極からの距離は回帰モデルの作成時には既知であるが， 診断時には未知であり，本研究では一般化線形混合乇 デルを用い，ランダム効果としての除去を試みる.

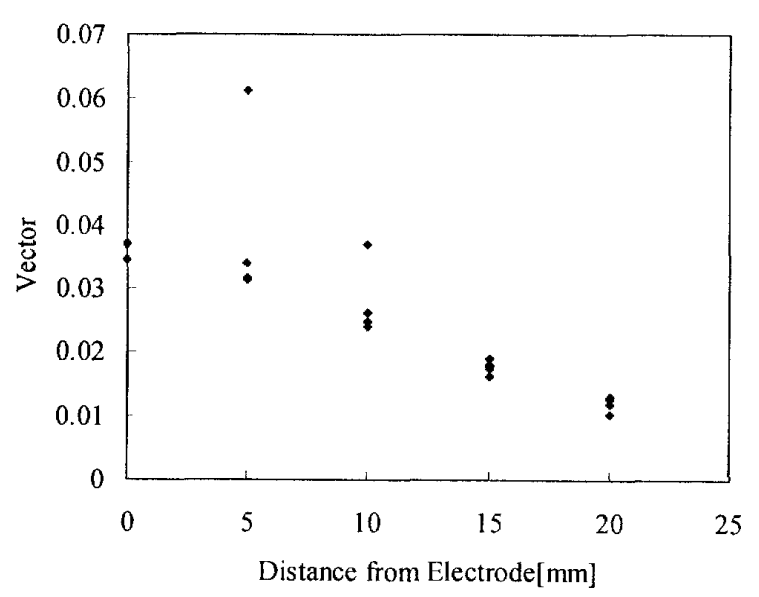

Fig2 Effect of the distance fiom the electrode to the vector (Delamination size: 20 $\mathrm{mm}$ )

\section{3 -6 一般化線形混合モテルによるランダム効果}

の推定 $3 \cdot 4$ より得られた 1 次の線形回帰式にラ ンダム効果を導入し，はく離損傷および位置の推定を 行う.ランダム効果はすでに述べたように，電極から の距離とした. 電極からの距離は両端 2 電極を除いた 中央 5 電極功の距離とする. 電極からの距離に応じ, 2 または 3 水準に分割し，水準毎にランダム効果の推 定を行う. ランダム効果は切片および vector の傾きと し, 最尤推定を行う。なお，各電極間の電圧変化量は vector で基淮化されており，注く離発生位置の影響は 殆ど無い. ランダム効果導入後の線形回帰式は次式と なる。

$$
\text { size }=\beta_{0}+\delta_{1}+\sum_{i=1}^{6} \beta_{i} X_{i}+\left(\beta_{7}+\delta_{2}\right) \text { vector }(10)
$$

$$
x=\beta_{0}+\delta_{1}+\left(\beta_{1}+\delta_{2}\right) X_{1}+\sum_{i=2}^{5} \beta_{i} X_{i}+\left(\beta_{6}+\delta_{3}\right) X_{6}
$$

ランダム効果は切片及び， $t$ 值が大きく回㷌への寄与の大き い変数一と設定している.

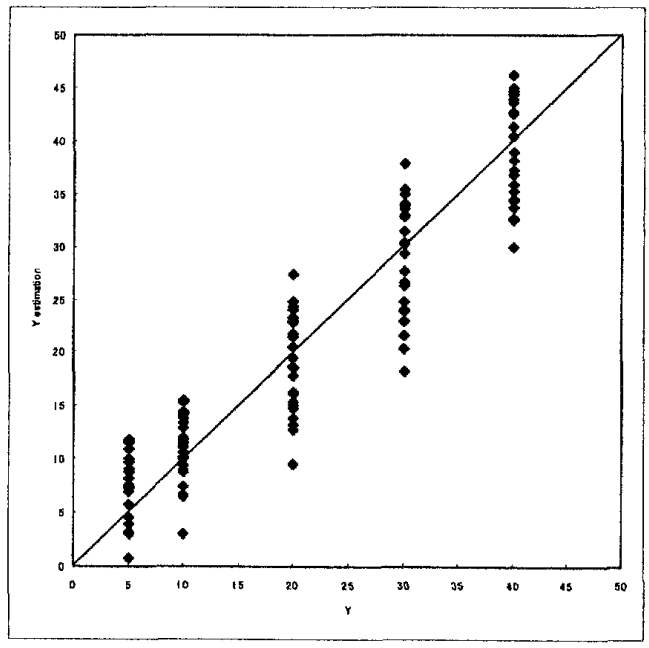

(a)Size

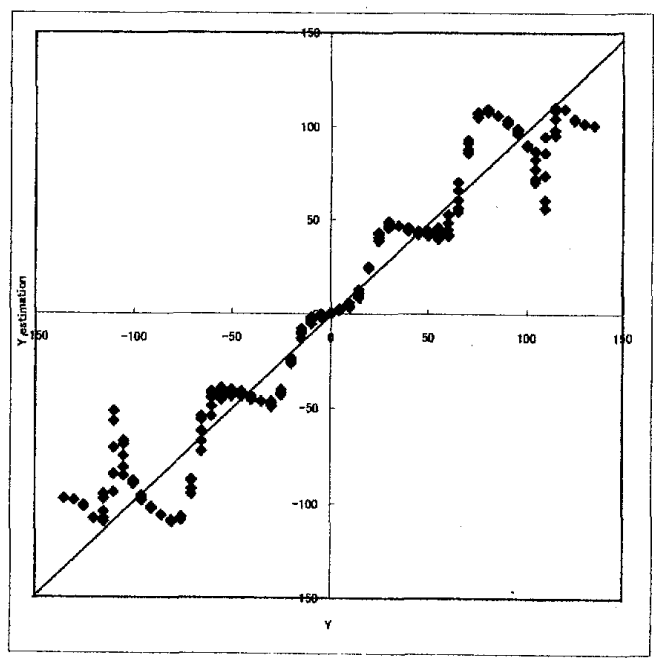

(b)Location

Fig3 Estimation of Size and Location of delamination without the random effect

\section{4. 解析結果}

\section{$4 \cdot 1$ ランダム効果を含まない場合の寸法・位置} 同定図3にランダム効果を含まない場合の位置, 寸法同定結果を示寸，寸法同定は寸法が 5 段階である ため，階段状の同定結果となるが，同定結果を水準分 割することにより，隣接水準までの同定となっており， 実用上問題のない精度と言える。 また，位置同定は特 に電極中央部付近で同定精度の低下が見られる。 寸法, 
位置同定にお汁る平均残差恬各々028, $1.12[\mathrm{~mm}]$, 最大 残差は各々 $11.7,58.1[\mathrm{~mm}]$ である. また，各々の回崹式 を次式示示。

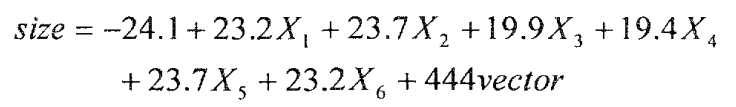

$x=6.84-103 X_{1}-57.1 X_{2}-9.09 X_{3}+47.9 X_{5}+92.6 X_{6}$

Table 2 Result of the estimation of size using the random effect (2 level)

\begin{tabular}{|c|c|c|c|c|}
\hline threshold & Random Effect & SSE & Max Error & AlC \\
\hline & None(Normal Response Surface) & $5.26 \mathrm{E}+03$ & 11.7 & 1476 \\
\hline$<5$ & \multirow[t]{4}{*}{ L } & $4.52 \mathrm{E}+03$ & 10.4 & $\lceil 443$ \\
\hline$<10$ & & $4.20 E+03$ & 9.0 & 1347 \\
\hline$<15$ & & $4.59 \mathrm{E}+03$ & 11.6 & 1263 \\
\hline$<20$ & & $6.00 \mathrm{E}+03$ & 14.0 & 1349 \\
\hline$<5$ & \multirow{4}{*}{ intercept } & $4.99 \mathrm{E}+03$ & 10.5 & 1433 \\
\hline$<10$ & & $4.52 \mathrm{E}+03$ & 9.4 & 1307 \\
\hline$<15$ & & $4.42 \mathrm{E}+03$ & 11.2 & 1219 \\
\hline$<20$ & & $4.97 \mathrm{E}+03$ & 11.9 & 1346 \\
\hline$<5$ & \multirow{4}{*}{ intercept + vector } & $4.99 \mathrm{E}+03$ & 10.5 & 1435 \\
\hline$<10$ & & $4.52 E+03$ & 9.4 & 1309 \\
\hline$<15$ & & $4.50 \mathrm{E}+03$ & 11.4 & $\$ 215$ \\
\hline$<20$ & & $5.55 \mathrm{E}+03$ & 13.2 & 1339 \\
\hline
\end{tabular}

\section{2 一般化線形混合モデルによる寸法・位置同定} 4:2:1 寸法同定 表 2 に電極加らの距離に忘じ 近(1)，遠(2)の 2 水準に分割した場合における分割範囲 毎の残差平方和 SSE, 自由度調整済夕決定係数 $R 2 a d$, 最 大残差を示寸。ランダム効果は表に示すように $10 \mathrm{~mm}$ を境とした場合に回帰精度が最大化し, 最大残差も最 小化すると言える. また，ランダム効果は vector の傾 きの外とする場合に精度が最大化する.

また，第 1 水準，第 2 水準の境孝 $10 \mathrm{~mm}$ とし，さら に3水準に分割した場合の結果を表 3 に示す，ランダ ム効果は vector の傾きのみとした．表に示すように, 第 23 水準の分割を $25 \mathrm{~mm}$ で行うことで残差平方和は 5260 から 4200 , 最大䛊差は $11.7[\mathrm{~mm}]$ 吅 $8.2[\mathrm{~mm}]$ と大 幅に精度の改善が可能と言える。また，この場合のは く離才法同定結果を図 4に示す。傾向としては応答曲 面法の場合と同じ結果を示しているが，最大残差およ ひ誤差幅が減少しており，精度の向上が確認される。

第 2,3水準の分割を $15,20,25[\mathrm{~mm}]$ で行った場合の，は く離寸法と vector の関係老図 5 に示吉. (a)から(c)八と 移行子るに従い明確に水準 2,3 が分割されていること が分かる. $25 \mathrm{~mm}$ で分割した際の固定効果は次式とな る.

$$
\begin{aligned}
\text { size }= & -25.4+15.9 X_{1}+17.4 X_{2}+13.9 X_{3}+13.9 X_{4} \\
& +17.4 X_{5}+15.9 X_{6}+152 \text { vector }
\end{aligned}
$$

$25 \mathrm{~mm}$ で分割した場合の水準 3 は試験片両端部でのは く離を示しておりこの部位ではく離が生じた場合, 電王変化量は寸法に比して大きな值を取り，この領域 を分割しランダム効果とすることで，より高い精度で 診断が可能々言える.

Table 3 Result of the estimation of size using the random effect (3 level)

\begin{tabular}{|l|l|r|r|}
\hline threshold & SSE & Max Error & AIC \\
\hline 2 level & $4.20 \mathrm{E}+03$ & 9.0 & 1347 \\
\hline$<15$ & $4.27 \mathrm{E}+03$ & 8.7 & 1337 \\
\hline$<20$ & $4.32 \mathrm{E}+03$ & 8.9 & 1378 \\
\hline$<25$ & $4.15 \mathrm{E}+03$ & 8.2 & 1357 \\
\hline$<30$ & $5.04 \mathrm{E}+03$ & 10.9 & 1342 \\
\hline$<35$ & $5.84 \mathrm{E}+03$ & 11.2 & 1318 \\
\hline
\end{tabular}

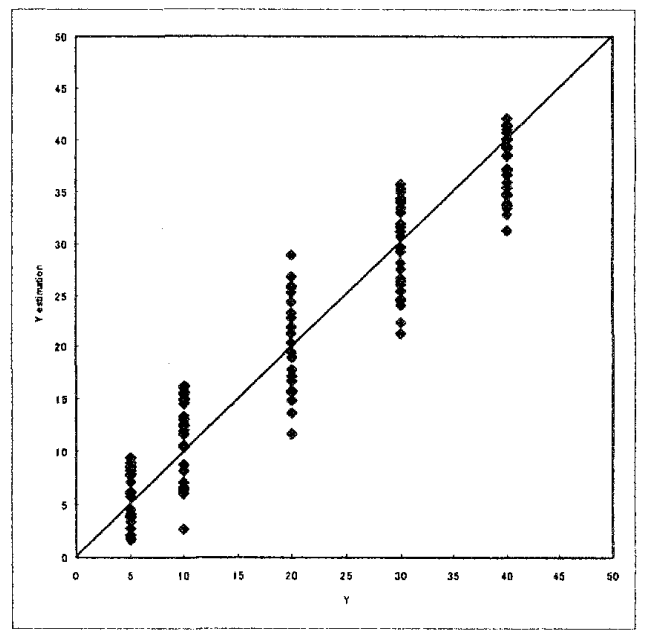

Fig 4 Estimation of Size of delamination using the generalized linear mixed model

$4 \cdot 2 \cdot 2$ 位置同定 同様の手順で位置同定を行っ た. 2 水準分割では領域で分割しても結果に変化はな か⿰たため，寸法と同じく $10 \mathrm{~mm}$ を基淮に分割し，さ らにもう1 水淮の分割を行った場合の結果を表 4 に示 す。この場合の同定結果を図 6に示寸。表に示すよう に大幅な改善は見られないが，第 3 水準の分割を $25 \mathrm{~mm}$ で行った場合，若干残差平方和の上昇が見られ た物の，最大誤差は減少している。これは図に見られ るように，位置同定では試験片雨端にはく㕍が位置す る場合に特に同定精度が低下するが，少数の両端にあ る場合を別の個体とすることで，近辺のゆがみを解消 したためと考えられる. 表 5 亿前述の voctor, $X_{i}$ に加え, 本来未知である実寸法，実位置および電極間距離を加 えた場合の回㷌係数および $t$ 值を示寺，ただし，相関 の低い係数を示寸ために $t$ 值による係数削減は行って 
いない，表に見られるように，才法と電極間距離は 值が 16.0 と高い相関を示すが，それ以外の相関はほぼ 0 と低い，そのため，才法同定に対しては大きな改善 効果を示寸が，位置に対しては大幅な効果は無いとい える。

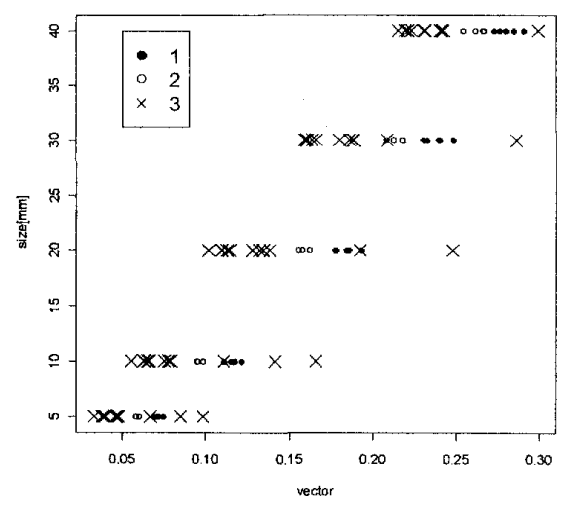

(a) $\mathrm{a}<10,10 \leqq \mathrm{a}<15, \mathrm{a} \geq 15$

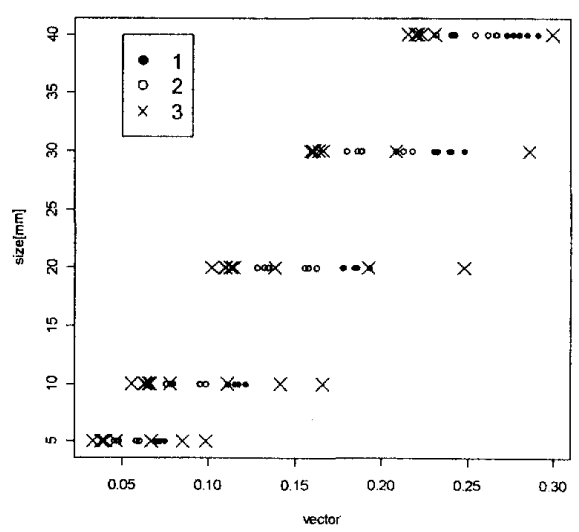

(b) $a<10,10 \leqq a<20, a \geqq 20$

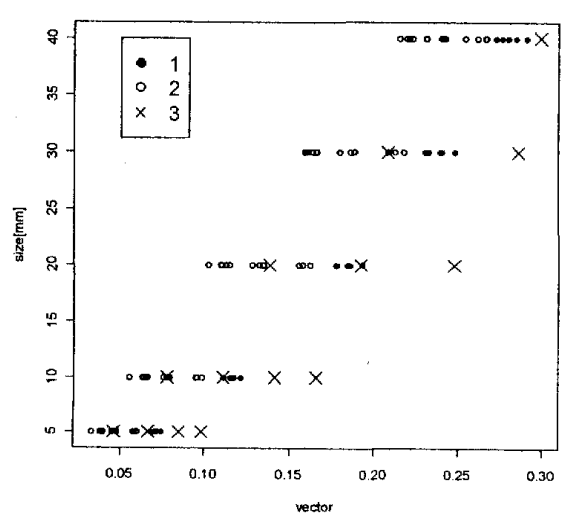

(c) $a<10,10 \leqq a<25, a \geqq 25$

Fig.5 Delamination size - vector of each leveling threshold (a: Distance between the delamination and the electrode)
Table 4 Result of the estimation of the location using the random effect (3level)

\begin{tabular}{|l|l|r|r|}
\hline threshold & SSE & Max Error & AIC \\
\hline Without Random Effect & $8.74 \mathrm{E}+04$ & 58.1 & 2263 \\
\hline$<15$ & $9.85 \mathrm{E}+04$ & 50.8 & 2232 \\
\hline$<20$ & $9.79 \mathrm{E}+04$ & 50.6 & 2194 \\
\hline$<25$ & $9.45 \mathrm{E}+04$ & 49.4 & 2163 \\
\hline$<30$ & $9.40 \mathrm{E}+04$ & 47.8 & 2179 \\
\hline$<35$ & $9.09 \mathrm{E}+04$ & 49.0 & 2197 \\
\hline
\end{tabular}

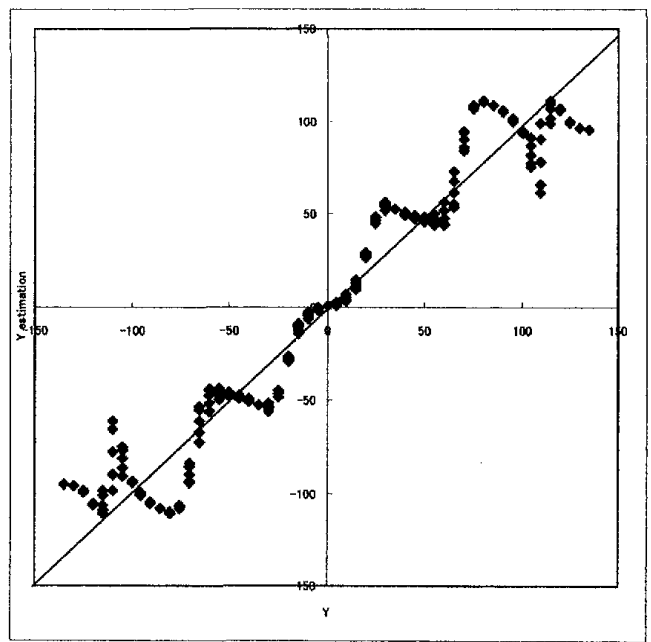

Fig.6 Estimation of location of delamination using the generalized linear mixed model

Table 5 The $t$-value and the regression coefficient of all independent variables and actual location and size for location/size diagnosis using linear regression model

\begin{tabular}{|c|c|c|c|c|}
\hline & Location Dagr & nosis & $\begin{array}{l}\text { Size Diagnos } \\
\text { Paf }\end{array}$ & \\
\hline Intercept & $1.66 \mathrm{E}-11$ & $8.13 \mathrm{E}-13$ & $\frac{1}{-21.4}$ & $\mid \begin{array}{l}\mid T-S t a t i s t i c \\
-9.5\end{array}$ \\
\hline Actual Size & $1.32 \mathrm{E}-13$ & $4.13 \mathrm{E}-13$ & 021.4 & -9.8 \\
\hline Actual Location & & - & $8.09 \mathrm{E}-15$ & 7.44E-13 \\
\hline vector & 0.00 & 0.00 & 487.2 & 57.0 \\
\hline $\mathrm{X} 1$ & -97.9 & -6.8 & 15.7 & 7.1 \\
\hline $\mathrm{x} 2$ & -52.4 & -3.3 & 16.7 & 9.2 \\
\hline$x_{3}$ & -5.1 & -0.4 & 13.8 & 8.6 \\
\hline $\mathrm{X} 4$ & 5.1 & 0.4 & 13.8 & 8.6 \\
\hline X5 & 52.4 & 3.3 & 16.7 & 9.2 \\
\hline $\mathrm{X} 6$ & 97.9 & 6,8 & 15.7 & 7.1 \\
\hline Distance From the Electrode & $-1.07 \mathrm{E}-13$ & $-5.58 \mathrm{E}-13$ & 0.5 & 16.0 \\
\hline
\end{tabular}

\section{5. 結言}

電気ポテンシャル法によるはく離損傷同定問題で は，はく離発生に起因する電纴変化が電極からの距離 に応じ変動し，診断精度へ大きな影響を与える. 本研 究では，この電極からの距離をランダム要因とし評価 することにより，一般化線形混合モデルによる同手法 の高精度化を行った．結果老以下に示す。

1. 総電圧変化の絶対值をパラメータの 1 つとし同定 を行う損傷寸法同定問題においては，電極加らの 距離をランダム要因として, vector の傾きを回帰 することで, 本手法により最大誤差および全体 的な誤差を低減し，診断精度を向上できること 
が確認された。

2. 電極加らの距離侍特に寸法と高い相関を示し， 一般化線型混合モデルを用いそれを考慮した回 帰分析を実施することで，同定の高精度化が可 能である。

3. 試験片両端部ではく離が生じた場合，電在変化 量は寸法に比して大きな值を取り，この領域を 分割しランダム效果とすることで，より高い精 度で診断が可能である。

\section{参考文献}

(1) Friswell, M.I, Damage identification using inverse methods, Philosophical Transaction, The Royal Society A, Vol.365(2007), pp.393-410

(2) Farrar, C.R., Worden, K. An introduction to structural health monitoring, Philosophical Thansaction, The Royal Society A, Vol365(2007), pp.303-315

(3) Inada, T. et al, Development of a Two-step Delamination Identification Method Using Resonant and Anti-Resonant Frequency Changes, Transactions of the Japan Society of Mechanical Engineers, Series A, Vol.69, No.678(2003), pp.231-238(in Japanese)

(4) Tanaka, Y., Todonoki, A., Shimamura, Y., Smart Structure for Delamination Detection of CFRP Using Response Surface of Electric Resistance Change of Multiple Electrodes, Transactions of the Japan Society of Mechanical Engineers, Series A, Vol65, No.640(1999), pp.2432-2438(in Japanese)

(5) Iwasaki, A., Todoroki, A., Diagnosis Method for Detection of Delamination of CFRP by Electric Resistance Change, J of the Japan Society for Composite Materials, Vol.27, No.4(2001), pp.194-200(in Japanese)

(6) Iwasaki, A, Todoroki, A, Statistical Evaluation of Modified Electrical Resistance Change Method for Delamination Monitoring of CFRP Plate, Structural Health Monitoring: An International Journal, Vol.4, No.2(2005), pp.119-136

(7) Okafor, A.O., Chandrashekhara, K, Jiang, Y.P., Delamination prediction in composites beams with built in piezoelectric devioes using modal analysis and neural network, Smart materials and structures, Vol.5(1996), pp.338-347

(8) Zapico, J.L, Worden, K, Molina, F.J., Vibration-based damage assessment in steel frames using neural networks, Smart Materials and Structures, Vol.10(2001), pp.553-559

(9) Sohn, H., Worden, K. Farrar, C.R., Statistical damage classification under changing environmental and operational conditions, J of Intelligent Material Systems Structure, Vol13(2002), pp.561-574.

(10) Ben, G., Yamaguchi, T., Fukuda, Y., Aoki, Y., Park, K.C., An Application on Localized Flexibility Method to Identification of Structural Joint Properties, Transactions of the Japan Society of Mechanical Engineers, Series A, Vol.66, No.644(2000), pp.721726 (in Japanese)
(11) Park, K.C., Felippa, C.A., A Variational Framework for Solution Method Developments in Structural Mechanics, Journal of Applied Mechanics, Vol.65, No.1(1998), pp.242-249

(12) Farrax, C.R., Nix, D.A., Duffey, T.A, P.J.Cornwell, G.C.Pardoen, Damage identification with linear discriminant operators, Proceedings 17th international Modal Analysis Conference(1999), pp.599-607

(13) Sohn, H., Allen, D., Worden, K, Farrar, R, Statistical Damage Classification using Sequential Probability Ratio Tests, Structural HealthMonitoring, Vol.2, No.1(2003), pp.57-74

(14) Iwasaki, A., Todoroki, A., Delamination Identification of CFRP Structure by Discriminant Analysis using Mahalanobis Distance, Key Engineering Materials, Vol. 270-273(2004), pp.1859-1865

(15) Sugimoto, H., Kazuma, K, Abe, J., Furukawa, K, On Synthetic Health Evaluation of Infrastructures by SVM and Its Application to Ranking of Structures, Proc of the Japan Society of Civil Engineering, Series A, Vol65, No.3(2009), pp.658-669(in Japanese)

(16) Worden, K., Iane, A.J., Damage identification using support vector machines, Smart Materials and Structures, Vol 10(2001), pp.540-547

(17) Iwasaki, A, Sano, T., Todoroki, A, Sakai, S., Delamination diagnosis of CFRP Structure using Support Vector Machine, Proc of the Conference of M\&M division of JSME 2004(2004), pp.287-288(in Japanese)

(18) Iwasaki, A., Todoroki, A., Izumi, S., Sakai, S., Diagnostic Method for Delamination Monitoring of CFRP Plate using Kriging Interpolation Method, Key Engineering Materials, Vol.353-358(2007), pp.14221426

(19) Breslow, N.E., Clayton, D.G., Approximate Inference in Generalized Linear Mixed Models, J of the American Statistical Association, Vol.88, No.421(1993), pp.9-25

(20) Kubo, T., Kasuya, E., Statistical Modeling of the Individual Specificity, Japanese Journal of Eoology, Vol.56, No.2(2006), pp.181-190(in Japanese)

(21) Moculloch, C.E., Searle, S.R., Neuhaus, JM, Generalized Linear, and Mixed Models(2008), Wiley Interscience

(22) Schulte K., Baron C., Load and failure analyses of CFRP laminates by means of electrical resistanoe measurement, Composite Science and Technology, Vol36(1989), pp.63-76.

(23) Todomki, A., Suzuki, Y., Kobayashi, H., Nakamura, H., Shimamura, Y., Evaluation of Orthotropic Electrical Resistance for Delamination Detection of CFRP by Electrical Potential Method, Transactions of the Japan Society of Mechanical Engineers, Series A, Vol64, No.622(1998, pp.1654-1659(in Japanese)

(24) Todoroki, A., Tanaka, M., Shimamura, Y., Kobayashi, $\mathrm{H}$., Analysis of the Effect of the Configuration of the Delamination Crack on Delamination Monitoring with Electric Resistance Change Method, J of the Japan Society for Composite Materials, Vol.29, No.3(2003), pp.113-119(in Japanese)

(25) Todoroki, A., Tanaka, M., Shimamura, Y., Kobayashi, H., Effects of Delamination Shape with a Matrix Crack 
on Monitoring by Electrical Resistance Method, Advanced Composite Materials, Vol.13, No.2(2004), pp.107-121.

(26) Todoroki, A., Tanaka, M., Shimamura, Electrical Resistanœ Change Method for Monitoring Delaminations of CFRP Laminates: Effect of Spacing between Electrodes, Composites Science and Technology, Vol.65, No.1(2005), pp.37-46

(27) Ueda, M., Todoroki, A, Delamination monitoring of quasi-isotropic CFRP laminate using electric potential change method, Modern Physics Letters B, Vol. 22 , No.11(2008), pp.869-874
(28) Ueda, M., Todoroki, A, Finite Element Study on Delamination Identification in Quasi-isotropic CFRP Laminate by Residual Stress Release Using the Electric Potential Change Method, J of Solid Mechanics and Materials Engineering, Vol. 2, No. 11 (2008), pp.1451-1461

(29) Todoroki, A, Omagari, K, Detection of matrix crack density of CFRP using electrical potential change method with multiple probes, Journal of Solid Mechanics and Materials Engineering, Vol.2, No.6(2008), pp.718-729 